\title{
Intonation structuring of coherent Tuvan folklore narration
}

\author{
Tatiana R. Ryzhikova, Albina A. Dobrinina, Ilya M. Plotnikov, \\ Elena A. Shestera, Anton S. Shamrin \\ Institute of Philology, Siberian Branch of the Russian Academy of Sciences, Novosibirsk, Russian Federation
}

The article presents preliminary data on the intonation of the Tuvan folklore narration with specific focus to the relation between intonation and text structure. The analysis was carried out on the basis of four Tuvan folklore texts. Three hypothetical intonational correlates of the text structure were examined. First, we consider the difference in tempo of the main parts of the texts, following the idea of three-part structure of folklore texts proposed by V. Propp (beginning, complication and ending). The data obtained show no direct correspondence between the tempo of an utterance and its position in the text, as the tempo of the first and the last utterances and their ratio to the average tempo vary significantly from text to text. Secondly, it is shown that the texts contain a number of metatext markers, which are used quite often and are distinguished by the means of intonation (including changes in tone and intensity and separation by a pause). Thirdly, verbal forms with particle-tyr performing similar functions are examined. In contrast to metatext markers, they are not characterized by any intonational prominence, as the tone and intensity follow the general line of declination marking the end of an utterance. Thus, intonation plays an important role in forming the structure of Tuvan folklore texts, which, however, manifests itself only indirectly, in the way of emphasizing lexical means of structuring the text (metatext markers).

Keywords: intonation; syntax; metatext markers; the Tuvan language; folklore; narrative tradition; Tuvan folklore

Financing:

The work is part of the project of the Institute of Philology of the Siberian Branch of the Russian Academy of Sciences "Cultural universals of verbal traditions of the peoples of Siberia and the Far East: folklore, literature, language" supported by a grant from the Government of the Russian Federation for the promotion of research conducted under the guidance of leading scientists, contract No 075-15-2019-1884.

For citation:

Ryzhikova T. R., Dobrinina A. A., Plotnikov I. M., Shestera E. A. and Shamrin A. S. Intonation structuring of coherent Tuvan folklore narration. New Research of Tuva, 2021, no. 4, pp. 101-118. DOI: https://www.doi.org/10.25178/nit.2021.4.8

RYZHIKOVA, Tatiana Raisovna, Candidate of Philology, Senior research fellow, Laboratory of Siberian and the Far Eastern Verbal Cultures, Institute of Philology, Siberian Branch of the Russian Academy of Sciences. Postal address: 8 Nikolayev St., 630090 Novosibirsk, Russia. Tel.: +7 (383) 330-53-46. E-mail: tanya12@mail.ru

ORCID ID: 0000-0001-6337-725X

DOBRININA, Albina Albertovna, Candidate of Phililogy, Research fellow, Laboratory of Siberian and the Far Eastern Verbal Cultures, Institute of Philology, Siberian Branch of the Russian Academy of Sciences. Postal address: 8 Nikolayev St., 630090 Novosibirsk, Russia. Tel.: +7 (383) 330-53-46. E-mail: ekinur@mail.ru ORCID ID: 0000-0001-5841-4714

PLOTNIKOV, Ilya Mikhailovich, Junior research fellow, Laboratory of Siberian and the Far Eastern Verbal Cultures, Institute of Philology, Siberian Branch of the Russian Academy of Sciences. Postal address: 8 Nikolayev St., 630090 Novosibirsk, Russia. Tel.: +7 (383) 330-53-46. E-mail: iliaplotnikov@gmail.com ORCID ID: 0000-0002-6416-689X

SHESTERA, Elena Aleksandrovna, Junior research fellow, Laboratory of Siberian and the Far Eastern Verbal Cultures, Institute of Philology, Siberian Branch of the Russian Academy of Sciences. Postal address: 8 Nikolayev St., 630090 Novosibirsk, Russia. Tel.: +7 (923) 172-05-78. E-mail: elena-schestera@mail.ru ORCID ID: 0000-0001-8440-136X

SHAMRIN, Anton Sergeyevich, Junior research fellow, Laboratory of Siberian and the Far Eastern Verbal Cultures, Institute of Philology, Siberian Branch of the Russian Academy of Sciences. Postal address: 8 Nikolayev St., 630090 Novosibirsk, Russia. Tel.: +7 (913) 951-42-20. E-mail: anton_shamrin@mail.ru ORCID ID: 0000-0001-5327-3369 


\title{
Интонационные универсалии в тувинском фольклорном повествовании
}

\author{
Татьяна Р. Рыжикова, Альбина А. Добринина, Илья М. Плотников, \\ Елена А. Шестера, Антон С. Шамрин
}

Институт филологии Сибирского отделения Российской академии наук, Российская Федерация

\begin{abstract}
В статье представлены предварительные данные по интонации тувинского фольклорного нарратива, причем особое внимание уделяется связи между интонацией и структурой текста. Анализ проводился на основе четырех тувинских фольклорных текстов. Была проверена гипотеза о зависимости интонации от структуры текста. Во-первых, рассматривалось различие темпа в основных частях текстов, в соответствии с трехчастной структурой фольклорных произведений, главным образом сказок, предложенной В. Проппом (начало, развитие и окончание). Полученные данные не показывают прямого соответствия между темпом произнесения и положением высказывания в тексте, поскольку темп первого и последнего высказываний и их отношение к среднему темпу значительно варьируются от текста $\mathrm{k}$ тексту. Во-вторых, показано, что в текстах присутствует ряд метатекстовых маркеров, которые используются довольно часто и выделяются средствами интонации (включая изменения тона, интенсивности и разделение паузой). В-третьих, рассматриваются глагольные формы с частицей-тыр, выполняющие аналогичные функции. В отличие от метатекстовых маркеров, они не характеризуются какой-либо интонационной выделенностью, поскольку их тон и интенсивность следуют общей линии деклинации, которая маркирует конец высказывания. Таким образом, интонация играет важную роль в формировании структуры тувинских фольклорных текстов, что, однако, проявляется лишь косвенно, в способе выделения лексических средств организации текста (метатекстовых маркеров).
\end{abstract}

Ключевые слова: интонация; синтаксис; метатекстовые маркеры; тувинский язык; фольклор; нарративная традиция; тувинский фольклор

Исследование выполнено в рамках проекта Института филологии СО РАН «Культурные универсалии вербальных традиций народов Сибири и Дальнего Востока: фольклор, литература, язык» по гранту Правительства РФ для государственной поддержки научных исследований, проводимых под руководством ведущих ученых (соглашение № 075-15-2019-1884).

\section{Для циитирования:}

Ryzhikova T. R., Dobrinina A. A., Plotnikov I. M., Shestera E. A. and Shamrin A. S. Intonation structuring of coherent Tuvan folklore narration // Новые исследования Тувы. 2021, № 4. C. 101-118. DOI: https://www.doi.org/10.25178/ nit.2021.4.8

Рыжикова Татьяна Раисовна - кандидат филологических наук, старший научный сотрудник Лаборатории вербальных культур Сибири и Дальнего Востока Института филологии СО РАН. Адрес: 630090, Россия, г. Новосибирск, ул. Николаева, д. 8. Тел.: +7 (383) 330-53-46. Эл. адрес: tanya12@mail.ru

Добринина Альбина Альбертовна - кандидат филологических наук, научный сотрудник Лаборатории вербальных культур Сибири и Дальнего Востока Института филологии СО РАН. Адрес: 630090, Россия, г. Новосибирск, ул. Николаева, д. 8. Тел.: +7 (383) 330-53-46. Эл. адрес: ekinur@mail.ru

Плотников Илья Михайлович - младший научный сотрудник Лаборатории вербальных культур Сибири и Дальнего Востока Института филологии СО РАН. Адрес: 630090, Россия, г. Новосибирск, ул. Николаева, д. 8. Тел.: +7 (383) 330-53-46. Эл. адрес: iliaplotnikov@gmail.com

Шестера Елена Александровна - младший научный сотрудник Лаборатории вербальных культур Сибири и Дальнего Востока Института филологии СО РАН. Адрес: 630090, Россия, г. Новосибирск, ул. Николаева, д. 8. Тел.: +7 (923) 172-05-78. Эл. адрес: elena-schestera@mail.ru

Шамрин Антон Сергеевич - младший научный сотрудник Лаборатории вербальных культур Сибири и Дальнего Востока Института филологии СО РАН. Адрес: 630090, Россия, г. Новосибирск, ул. Николаева, д. 8. Тел.: +7 (913) 951-42-20. Эл. адрес: anton_shamrin@mail.ru 


\section{Introduction}

Tuvan (formerly known as Uriankhai, Soyot) is the language spoken by the aboriginal people of the Republic of Tuva and the South of the Krasnoyarsk Krai, with Tuvan ethnic groups also found in Mongolia and in the Xinjiang Uyghur Autonomous Region of China (Bavuu-Surun, 2010: 58). The total number of speakers is estimated at 270,000 people (2015), including about 253,700 people (2010 census) in Russia, about 10,000 in Mongolia, and about 5,000 in China ${ }^{1}$. Of the Tuvans living on the territory of Tuva, $98 \%$ consider Tuvan as their native language (Bavuu-Surun, 2010: 58).

According to the genealogical classification, Tuvan belongs to the Siberian group of the Turkic family of the Altai language macrofamily (Scherbak, 1994: 39). L. Johanson considers Tuvan to be part of the Northeastern (or Siberian), a southern, South Siberian, subbranch comprising Sayan Turkic, i.e. Tuvan, Tofan, Soyot, Dukhan, Tuhan, etc., and non-Sayan Turkic, i. e. Khakas, Shor, North Altay, Chulym, etc. (Johanson, 1998). There are four dialects of Tuvan: Central (which is considered in this paper), Western, North-Eastern (Todzhinsky) and South-Eastern.

The articulatory-acoustic base (AAB) is a dynamic stereotype formed at an early stage of an ethnic group's existence and providing means of expression in the verbal communication. Changing with the course of the group's development, $\mathrm{AAB}$ preserves its constituent (dominant) features as long as the ethnic community keeps its compact residence (Nadelyaev, 1980: 5-6; 1986). The AAB of the Tuvan language was experimentally described on the segmental sublevel (Bicheldey K., 1989, 2001; Dambyra, 2005; Kechil-ool, 2006), with the suprasegmental one remaining completely undescribed. The works of Sh. Sat (Sat, 1983) provide a brief description of Tuvan intonation and accentuation, but these are only general remarks based on auditory perception. For example, Sh. Sat writes that the Tuvan narrative sentence is characterized by a level tone without sharp rises and falls of F0. The intonation contour of an utterance is rising-falling (ascendingdescending).

The monograph by F. Iskhakov and A. Palmbakh (Iskhakov, Palmbakh, 1961), which is fundamental for the Tuvan linguistics, covering both phonetics and grammar, does not mention the prosodic characteristics even in passing. In 2020, at the 11th International Conference of Experimental Linguistics T. Ryzhikova and others (Ryzhikova, Dobrinina, Plotnikov, 2020) presented a small paper addressing the problem of intonation in Tuvan modal (yes/no) questions. The authors did not manage to establish any definite correlation between intonation pattern and modal interrogativity because F0 can either rise, or remain level, or even fall on special interrogative particle $b e$ (Ibid.), unlike the Altai language, in which analogous particle $b a$ is obligatorily marked with the rising of F0 (Ryzhikova et al., 2020).

Generally, intonation in Siberian Turkic languages remains poorly investigated. There are some experimental-phonetic descriptions of individual languages, e.g. Yakut (Alekseev, 1982, 1983, 1990, 1992, 1994; Sidorova, 2012), Khakas (Bicheldey K., 2000, 2001; Burnakova, 1981, 1986, 2014), Telengit (Gertsog, 1986, 1988, 1989), Teleut (Shestera, 2014, 2018). Great contribution into the study of the Turkic prosody was made by U. Baitchura (Baitchura, 1959, 1961, 1970, 1971). Kh. Salimov studied the prosody of the literary Tatar (Salimov, 1986, 1999). Recently there have appeared several investigations of Volga Tatar made by foreign phoneticians (Royer, 2017; Royer, Jun, 2018, 2019). There are also prosodic studies of the neighboring languages such as Azerbaijani (Veyselli, 2013; Alieva, 2007, 2012) and Kazakh (Turkbenbaev, 1966; Bazarbaeva, 2008). In-depth research of the Turkish intonation is being carried out by a number of scholars (Levi, 2002; Kawaguchi, Yilmaz, Uras, 2006; Ipek, Jun, 2013; Kühn, 2016).

All the abovementioned works are devoted to the study of colloquial speech in different forms, but to the authors' knowledge, there are only a few intonational studies of a coherent text (see, e. g. Yanko, 1999) and no similar investigations on the material of the Turkic languages (at least in Siberia). It is widely accepted that the area of supersegmental phonetics is understudied in many languages, thus it will still be premature to make any conclusions about typological characteristics of the intonation of the Turkic languages. Taking into account the specific nature of folklore narratives, the purpose of the present paper is to study the role that intonation plays in forming the structure of a text.

${ }^{1}$ Simchit A. K.-M. (2017) Tuvinskiy Yazyk [The Tuvan language]. In: Bol’shaya rossiiskaia entsiklopedia [Big Russian Encyclopaedia] [online] Available at: https://bigenc.ru/linguistics/text/4218682 (accesse date: 01.09.2021). 


\section{Materials and methods}

The well-known Siberian folklorist N. A. Alekseev considers the mythology of the Turkic-speaking ethnic groups of Siberia as a set of folklore works reflecting these peoples' awareness of the Universe based on the recognition of its multiplicity, i. e. the existence of interconnected parallel worlds: Upper, Middle, and Lower, as well as the multidimensionality of these worlds: the ability of beings located there to transit from one world to another and impact each other (Alekseev, 1980, 1992).

The myths of the Siberian peoples can be divided into sacred and profane. The first ones were considered to be sacramental secret knowledge shared only by experts and leaders of sacred rites: priests of the cult of the clan or tribe patron deities, shamans - people with the gift of penetrating other worlds and interacting with their inhabitants. Profane myths were known to all members of specific societies, and it is these texts that are mostly available to the collectors.

In the Tuvan language, different words can denote a myth: dip buder shagda chugaalar 'stories of the world creation', erte-burun shagnyng chugaalary 'stories of ancient times', eldep chugaalar 'strange stories', korgunchug, surtenchig chugaalar 'scary stories', khoruglug chugaalar 'forbidden stories', etc. N. A. Alekseev and his colleagues suggested using one complex word to refer to a myth: burun-chugaa 'ancient story'. As the most understandable and capacious, this term meets the main criteria of a myth: it emphasizes the age of the event and the belief in its authenticity, also indicating the narrative nature of the work (Pamiatniki fol'klora ..., 2010: 12).

The second group of the texts includes the stories about significant events in the life of the ethnic group in the past and present, about facts that caused admiration, surprise, or discussion among eyewitnesses. According to the degree of reliability, these stories can be divided into historical tales (töögu chugaalar) and legends (toolchurgu chugaalar). Historical stories, over time, acquire additional details: being retold many times, they are hyperbolized and pass into the category of legends, the works where real events are supplemented by fiction. Both types of folklore texts will be considered below.

In our work, we have used audio files from the compact disc attached to "Myths, Legends, Historical Stories of Tuvans (2010)", volume 28 in the folklore series "Monuments of the folklore of the Peoples of Siberia and the Far East". Four texts were selected for analysis, with durations of 3.41, 3.38, 9.38, and 4.55 minutes (one myth and three legends). All of them have a written text in Tuvan and its Russian translation. The myth was narrated by a professional storyteller (toolchu) and shaman, while the first legend was told by a teacher of the Tuvan language, the second legend was narrated by a Buddhist temple abbot, and the third legend, by a stone carver, with all of them being ethnic Tuvans and native speakers of Tuvan.

The audio files were converted from WMA format into WAV and then segmented into utterances (154 units in total) using the Audacity program, with their boundaries coinciding with the ends of the sentences. For further analysis, segment boundaries and pauses were set manually, using Praat ${ }^{1}$ and following the syllable division criteria for the Turkic languages. Four levels of segmentation were implemented: sentence, clause, word, and syllable. The analysis was carried out both manually and automatically at the syllabic level.

\section{Intonational correlates of the text structure}

In this work, we follow V. Propp's idea of structural similarity of fairy tales. In his book "Morfologiya volshebnoy skazki” (Morphology of a Fairy Tale) (Propp, 2001), Propp analyzes different types of fairy tales and concludes that the simple structure of any tale consists of three main parts: zachin (beginning or exposition), development of the plot (complication) and ending. It goes without saying that there are structures that are much more complicated, but we shall not consider them here as the texts under consideration have quite simple ones. Thus, we have divided the texts under consideration into three typical parts: beginning, complication and ending.

\footnotetext{
${ }^{1}$ Boersma, P., Weenink, D. (2017). Praat: Doing phonetics by computer (6.0.32) [Computer software]. Retrieved from www.praat.org
} 


\section{Tempo}

In accordance with Propp's classification, our preliminary hypothesis was that generally myths and legends might differ in the intonation of their constituent parts (mainly by the speech tempo). To verify this supposition, a preliminary segmentation of the texts was performed and sentences belonging to the exposition, the complication and the ending were temporally compared. The idea was that the exposition and the ending would be pronounced more slowly than the complication.

The results turned out to be inconclusive. The average syllable length was calculated using the formula

$\mathrm{T}_{\text {mean/syl }}=\mathrm{T}_{\text {total }} / \mathrm{N}_{\text {syl }}$,

where $\mathrm{T}_{\text {mean/syl }}$ is an average pronunciation time of a syllable, $\mathrm{T}_{\text {total }}-$ the total length of an utterance, and $\mathrm{N}_{\text {syl }}$ - the number of syllables. The calculation showed that the sentences classified as belonging to the exposition and the ending were in some cases delivered faster than those in the complication, which contradicts our hypothesis. It might be due to the rather short and simple structure of these sentences comprising only one or two predicative clauses. However, Tuvan speech tends to involve lengthy verbal periods, syntactic constructions, abundant adverbial turns, and difficult predication (Pamiatniki fol'klora ..., 2010: 290). This is typical for the middle part of the texts under study, and may have affected the tempo of the complication utterances. The results of the calculations are presented in Table 1.

Table 1. Comparison of the average syllable lengths in different parts of the texts, in seconds. Табл.1. Средняя длина слога в разных частях текста, в секундах.

\begin{tabular}{|c|c|c|c|c|c|}
\hline Text & First utterance & Second utterance & $\begin{array}{c}\text { Average } \\
\text { utterance }\end{array}$ & Second to last utterance & Last utterance \\
\hline 65 & 0.23 & 0.17 & 0.18 & 0.15 & 0.16 \\
\hline 103 & 0.29 & 0.22 & 0.22 & 0.21 & 0.26 \\
\hline 105 & 0.22 & 0.25 & 0.20 & 0.21 & 0.21 \\
\hline 106 & 0.18 & 0.24 & 0.19 & 0.19 & 0.13 \\
\hline
\end{tabular}

The exposition is generally faster than the average, but this trend is not distributed evenly across all the utterances: in text 106, the first utterance has an average tempo, while the second is noticeably slower, and in 65 and 103, the second utterance has a noticeable increase in tempo. The ending tempo also varies: it is faster than the average in 65 and 106 and slower in 103 and 105, with noticeable acceleration (106) and deceleration (103) when comparing the last two utterances.

\section{Metatext markers}

Outwardly, Siberian peoples' myths and legends are usually ordinary narratives without colourful, poetic descriptions, but they are characterized by constant verbal signs, including a number of set expressions serving as markers of the parts of a text (Propp, 2001; Kuzmina, 2005). The most typical initial common places in Tuvan are shag shaanda 'once upon a time', shiyaan am 'so, well'. Typical finalizing expressions are oon beer 'since that time' and ynchangash 'therefore', emphasizing the general explanatory function of myths and legends (Pamiatniki fol'klora ..., 2010: 31). As these expressions are associated with specific parts of a text and generally perform the function of organizing its structure, we consider them as a part of metatext a set of secondary linguistic means used to establish connection between sentences and help the listener to reconstruct the entire text through these connections (Wierzbicka, 1978). Such expressions herein will be referred to as metatext markers.

In the texts under consideration, these metatext markers proved to be used quite regularly. The starting construction is usually shag shaanda 'once upon a time' or yncharga shaanda 'in old times'. There are several examples of thier usage. 
(1) Ynchaarga shaanda Köp-Söök hüreezi Köp-Söök shynaazynyng kydyynga turgan üe.

\begin{tabular}{lcccc} 
yncha=ar=ga & shaanda Köp-Söök & hüree=zi & \multicolumn{2}{c}{ Köp-Söök } \\
do so=PrP=DAT ${ }^{1}$ & long ago Köp-Söök & monastery =POSS.3SG & Köp-Söök \\
shynaa=zy=nyng & $\begin{array}{l}\text { kydyy=n=ga } \\
\text { lowland=POSS.3SG=GEN }\end{array}$ & tur=gan & üe \\
bank.POSS.3SG=INFIX=DAT & be=PP & time
\end{tabular}

'In old times, the Kop-Sook khuree was located on the edge of the Kop-Sook Valley.'
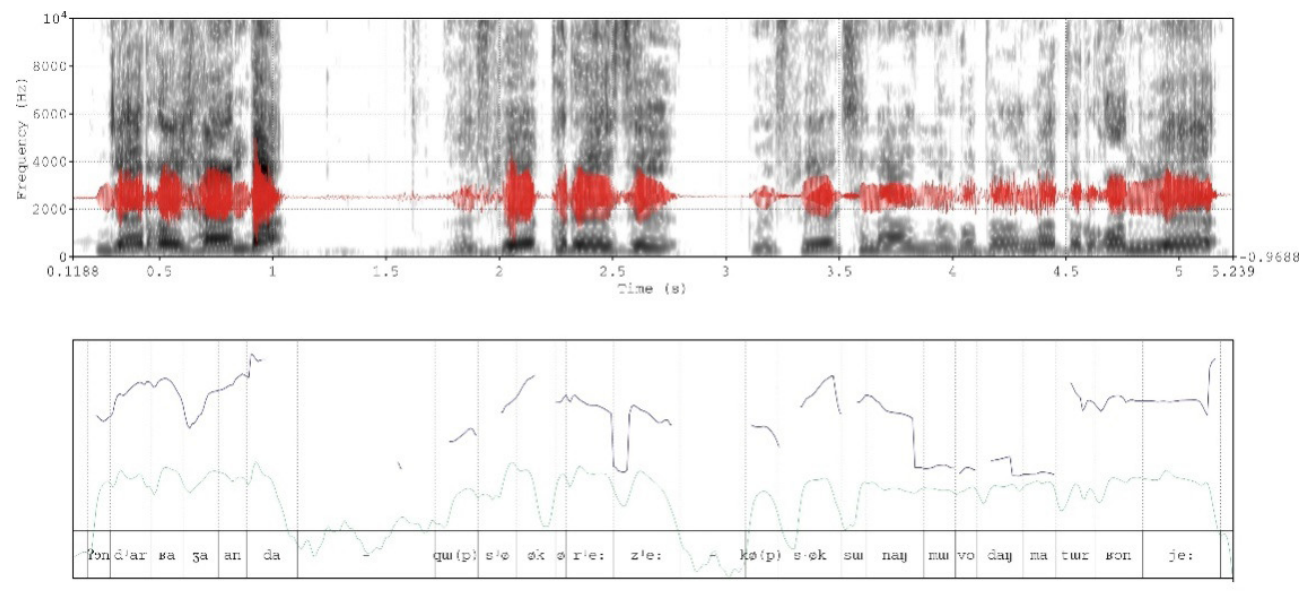

Fig. 1. Intonogram of the Tuvan utterance with the initial metatext marker ynchaarga shaanda 'in old times'. Рис. 1. Интонограмма тувинской фразы, в начале которой присутствует метатекстовый маркер ынчаарга шаанда 'в старые времена'.

In this example, the metatextual marker is the adverbial modifier ynchaarga shaanda 'in old times'. It occupies a precore periphery position in the sentence and has rising-falling-rising pitch movement. It starts from $11 \mathrm{st}^{2}$, then rises up to $17.5 \mathrm{st}$, by the end of ynchaarga it again falls to $10.6 \mathrm{st}$, and after that dramatically rises almost to $20 \mathrm{st}$, implying that it is not the end of the utterance and some further information will follow. Intensity is also rather high here, with two maximum peaks on the last syllables of both words ynchaarga and shaanda. The metatext marker is also separated by a pause.

(2) Shag-shaanda am bisting bo Baj-Tajga deviskeeringe myndyg boluushkunnar baza bolup turgan. Oon söölzüredir ol am toolchurgu chugaalar bolgan-dyr am.

shag-shaanda am bis=ting bo

$\begin{array}{lc}\text { Baj-Tajga } & \text { deviskeer= } \mathrm{i}=\mathrm{n}=\mathrm{ge} \\ \text { Baj-Tajga } & \text { territory=POSS.3SG=INFIX=DAT } \\ \text { baza bol=up } & \text { tur=gan } \\ \text { also be=CV } & \text { stand=PP }\end{array}$

long ago so we $=$ GEN this

myndyg boluushkun=nar

such event=PL

also $\quad$ be $=\mathrm{CV}$

stand $=\mathrm{PP}$

'Once upon a time in the land of our Bai-Taiga, there were such cases. They later became legends.'

\footnotetext{
${ }^{1}$ Glosses:= - morpheme separation; 1 - 1st person subject ('I’, 'we'); 2 - 2nd person subject (singular 'you', plural 'you'); 3 - 3rd person subject ('he', 'she', 'it', 'they')

Combinations of grammatical meanings: $\mathrm{ABL}-$ ablative; $\mathrm{ACC}-$ accusative; $\mathrm{CV}-$ converb on $=p$; CV2 - converb on $=a$; DAT - dative; GEN - genitive; IMP - imperative; INFIX - infix; LOC - locative; PERF - perfective; PL - plural; POSS - possessive marker; PP - past participle on $=$ gan; PrP - present participle on $=a r$; PRTCL - particle; RECIP reciprocal; SG - singular.

${ }^{2}$ st- semitones.
} 

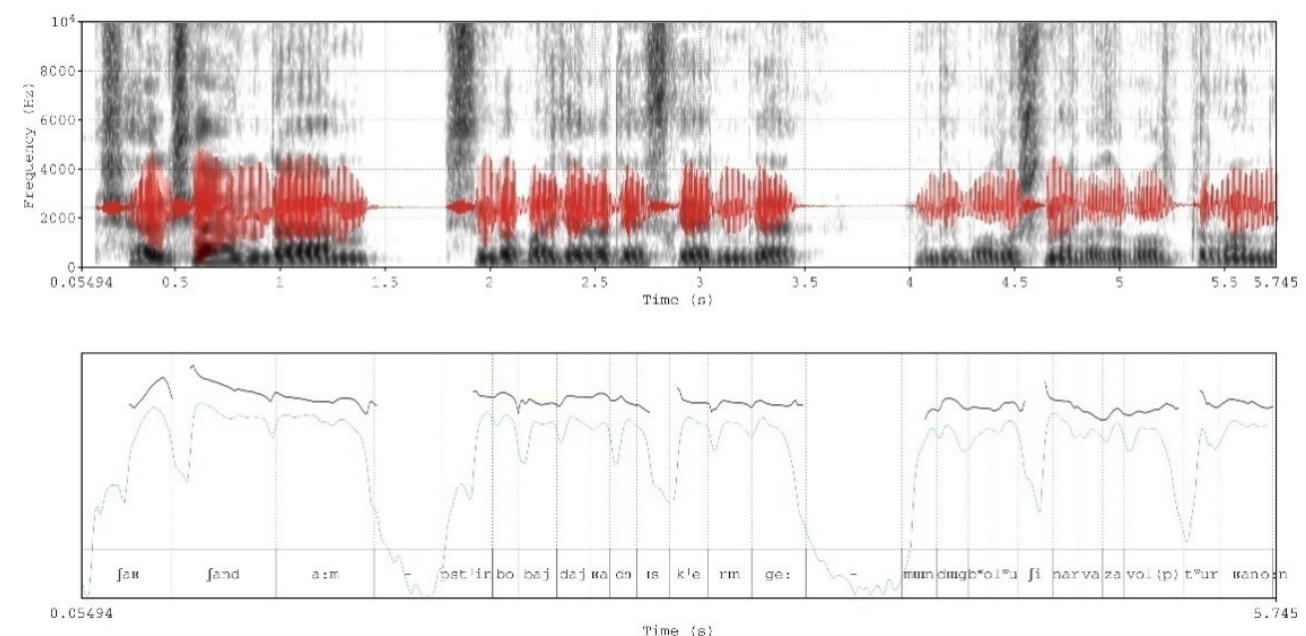

Fig. 2. Intonogram of the Tuvan utterance with the initial metatext marker shag shaanda 'once upon a time'. Pис. 2. Интонограмма тувинской фразы, в начале которой присутствует метатекстовый маркер шаг шаанда 'давным-давно'.

The sentence under consideration starts with shag shaanda 'once upon a time' followed by the word am 'so'. The intonation contour is rising-falling with a level ending. The maximum peaks of intensity are on shag and the first syllable of shaanda. The introductory phrase is also marked by a pause.

(3) Hemchik shag-shaanda hereezhen kizhi boop bodaraan.

$\begin{array}{lllll}\text { Hemchik shag-shaanda } & \text { hereezhen } & \text { kizhi boop bodaraan } \\ \text { Hemchik } & \text { longago } & \text { woman } & \text { person be.CV disseminate.RR }\end{array}$

'[The river] Khemchik was created long ago in the form of a woman.'
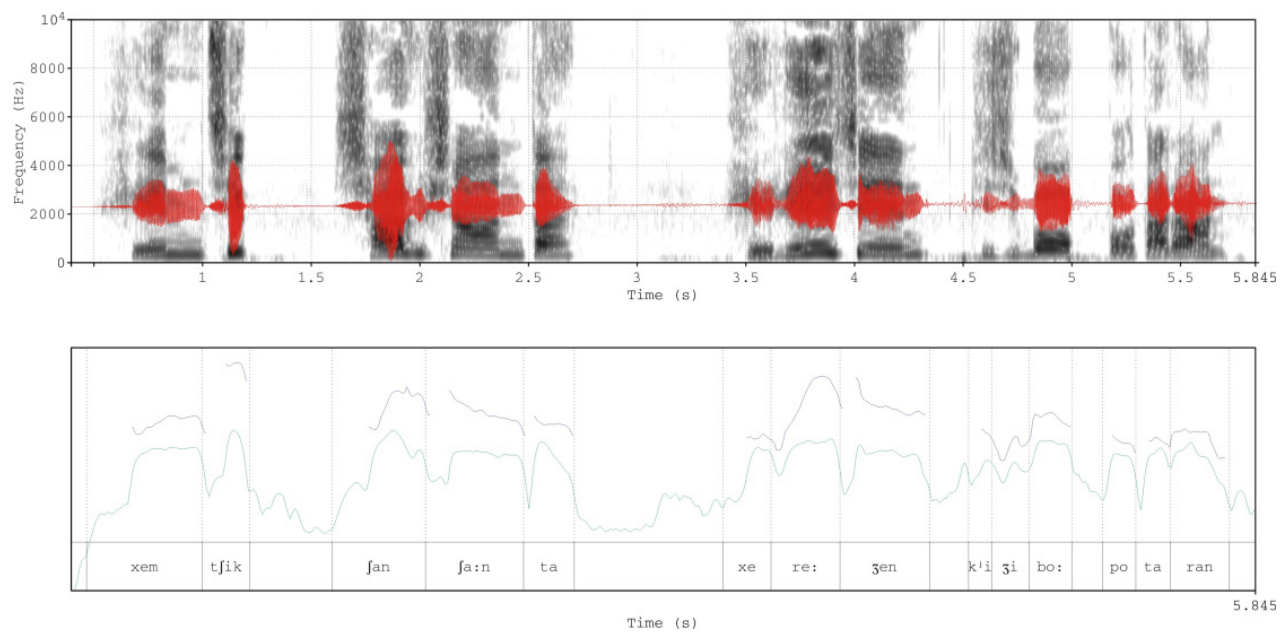

Fig. 3. Intonogram of the utterance with the initial metatext marker shag shaanda 'once upon a time'. Рис. 3. Интонограмма высказывания с начальным метатекстовым маркером шаг шаанда 'давным давно'.

In this example, the metatext marker shag shaanda 'once upon a time' occupies the position not in the very beginning of the sentence but after the subject Khemchik and is separated by pauses before and after it. The F0 movement is rising-falling, with maximum intensity and tone on shag, the second peak located on the last syllable of shaanda.

In the middle part of the texts, the phrases such as yncharga 'then', ynchaldyr 'so', ynchap turgash 'thus', oong söölünde 'after that', oon söölzüredir 'afterwards', am 'when', am oon 'then', ol-la 'so' occur rather often. In addition, one can see phrases such as birle kitap 'once', birle khün, bir khün 'one day'. 
(4) Ynchaarga, dungmazy: - Shynap-la, akyj, dilep choruptaalam - deen.

$\begin{array}{lclll}\begin{array}{l}\text { yncha=ar=ga } \\ \text { soto do=PrP=DAT }\end{array} & \begin{array}{c}\text { dungma=zy } \\ \text { younger brother=POSS.3SG } \\ \text { chor=upt=aalam }\end{array} & \begin{array}{l}\text { shynap-la } \\ \text { indeed-PRTCL }\end{array} & \begin{array}{l}\text { akyj } \\ \text { elder brother }\end{array} & \begin{array}{l}\text { dile=p } \\ \text { ao=PE=CV }\end{array} \\ \text { gor=IMP2=1Sg } & \text { say.PP } & & \end{array}$

'Then the younger brother continued: - Indeed, my big brother, let's go and look for [her].'
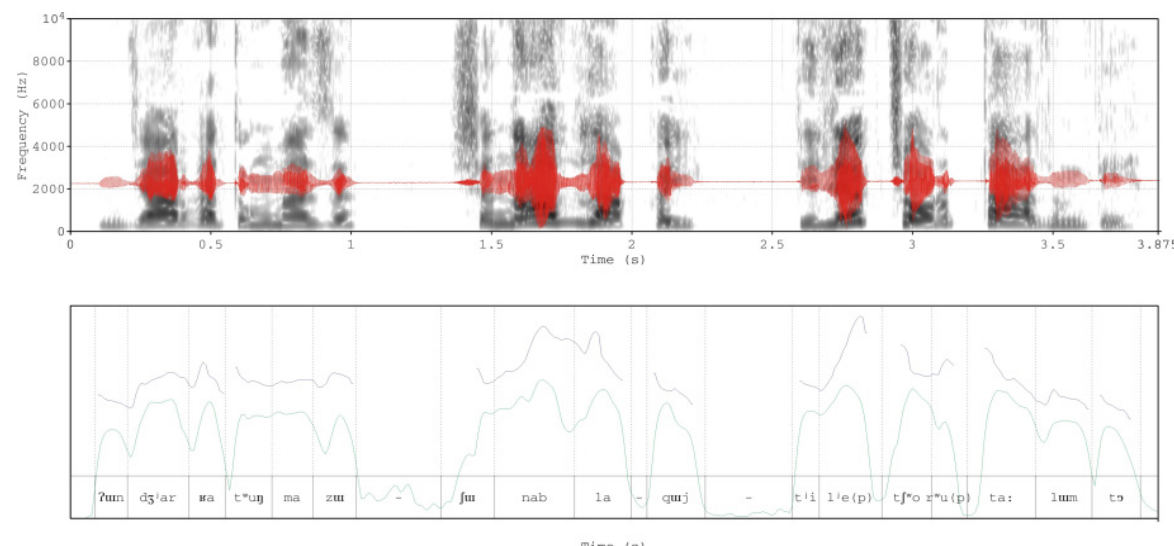

Fig. 4. Intonogram of the Tuvan utterance with the initial metatext marker yncharga 'then'. Рис. 4. Интонограмма тувинской фразы, в начале которой присутствует метатекстовый маркер ынчаарга 'затем, потом'.

In this example, the adverb yncharga 'then' plays the role of a metatext marker but is a part of a longer phrase ynchaarga, dungmazy 'then the younger brother [continued]' and is not separated by a pause though the intonation contour (rising-falling) is similar to the previous examples. Generally, the intensity is higher on ynchaarga rather than on dungmazy.

(5) Oong söölünde ol Köp-Söök hüreezinge, mangaa keerge, bisting bo azhyk arazynga bezhen hire ög churttap turar. 'After that, [when] he came to Kop-Sook khuree, there were about fifty families living there between the open places in the forest.'

Oong söölünde ol Köp-Söök hüreezinge <...>.

$\begin{array}{llll}\text { oong } & \text { sööl= } \ddot{\mathrm{u}}=\mathrm{n}=\mathrm{de} & \text { ol } & \text { Köp-Söök } \\ \text { this.GEN } & \text { end=POSS.3SG=INFIX=LOC } & \text { that } & \text { Kop-Sook }\end{array}$

hüree $=\mathrm{zi}=\mathrm{n}=$ ge

monastery=POSS.3SG=INFIX=DAT

'After that, [when] he came to Kop-Sook khuree <...>.'
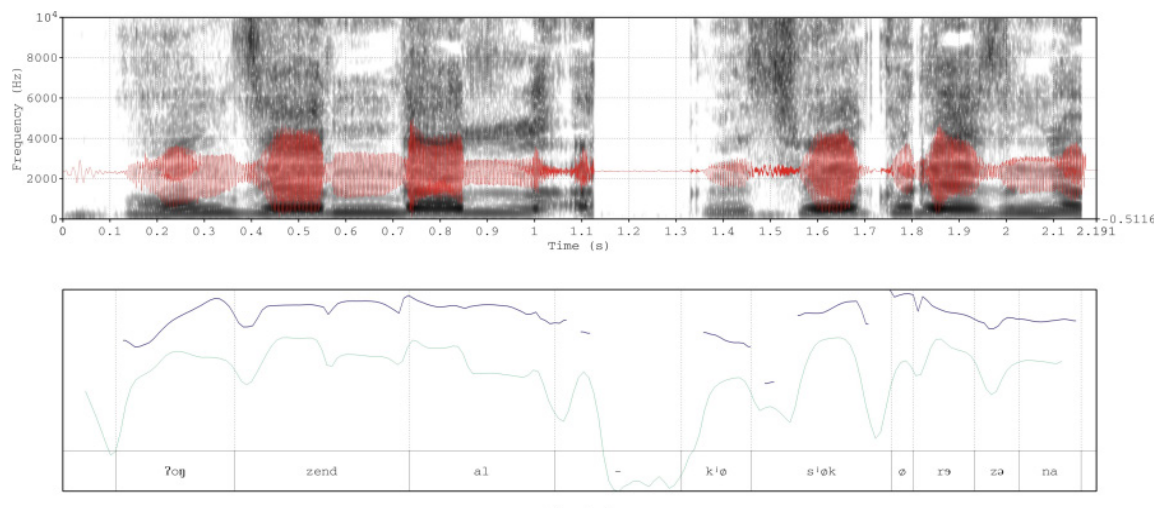

Fig. 5. Intonogram of the Tuvan utterance with the initial metatext marker oong söölünde 'after that'. Рис. 5. Интонограмма тувинской фразы, в начале которой присутствует метатекстовый маркер ооң сөөлүнде 'после того'. 
While pronouncing the metatext marker oong söölünde 'after that', the speaker included the pronoun $o l$ 'this, that' into the intonation phrase and separated it from the rest of the utterance by a pause. The tone movement is rising-falling. The intensity peak is on söölünde.

(6) Oong söölünde am Köp-Söök hureezinge dedir chede beerge, anchan kozhuunnung chyzaan bashtaar cherining dargazynga Ezutu dep kizhi turgan. Ol kizhi chaa ovaany tutturup kaan.

$\begin{array}{llll}\text { oong sööl=ü=n=de } & \text { am } & \text { Köp-Söök } \\ \text { this.GEN end=POSS.3SG=INFIX=LOC } & \text { PRTCL } & \text { Köp-Söök } \\ \text { hüree=zi=n=ge } & \text { dedir } & \text { ched=e } & \text { beer=ge } \\ \text { monastery=POSS.3SG=INFIX=DAT } & \text { back } & \text { reach=CV2 } & \text { give.PrP=DAT }\end{array}$

'Then, when we returned to Kop-Sook khuree, at that time the monastery was run by a man named Ezutu. This man ordered the construction of a new ovaa ${ }^{1}$ '.
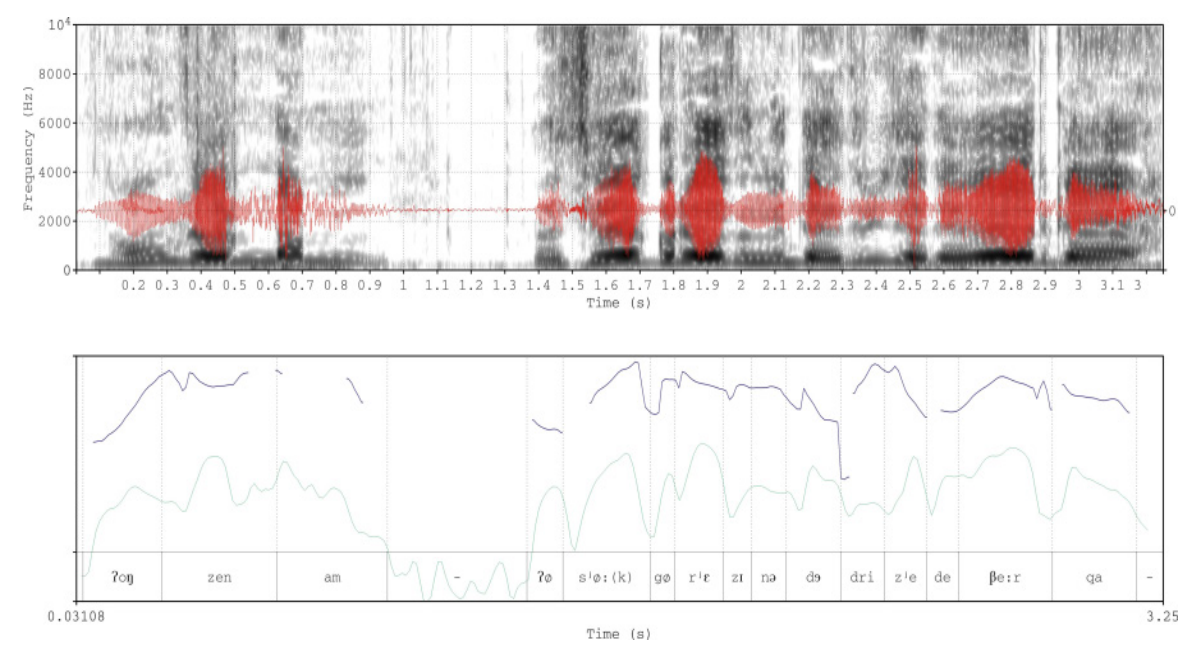

Fig. 6. Intonogram of the Tuvan utterance with the initial metatext marker oong söölünde 'after that'. Рис. 6. Интонограмма тувинской фразы, в начале которой присутствует метатекстовый маркер ооң сөөлүнде 'после того, затем'.

In this sentence, the phrase oong söölünde 'after that' is also accompanied by the adverb am 'when' and is separated from the rest of the utterance by a pause. On the first part of the phrase, the tone is rising, while on the last word am, it declines. As in the previous example, the maximum intensity is also on the word söölünde.

The storytellers usually use both oon beer 'since that time' and ynchangash 'therefore' to finish the narration. Shown below are some examples of such utterances.

(7) Ynchangash ol chadyr bolza ür üening ishtinde turup kelgen.

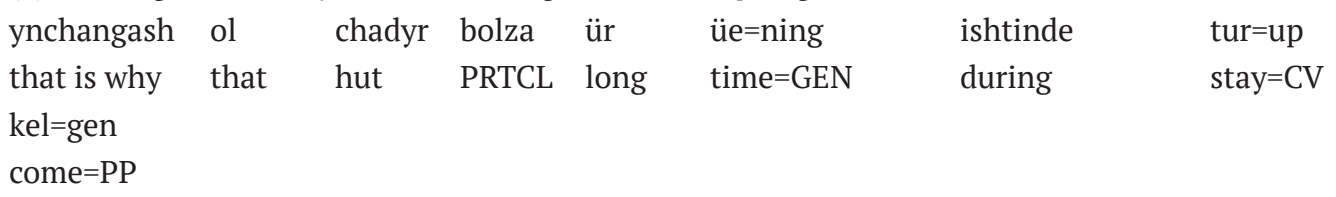

'Therefore that hut stood for a long time [empty].'

\footnotetext{
${ }^{1}$ ovaa - old. ova, sacrificial mound (a pile of stones on an elevated place, where a religious ceremony was performed in honour of the spirit of the mountain).
} 

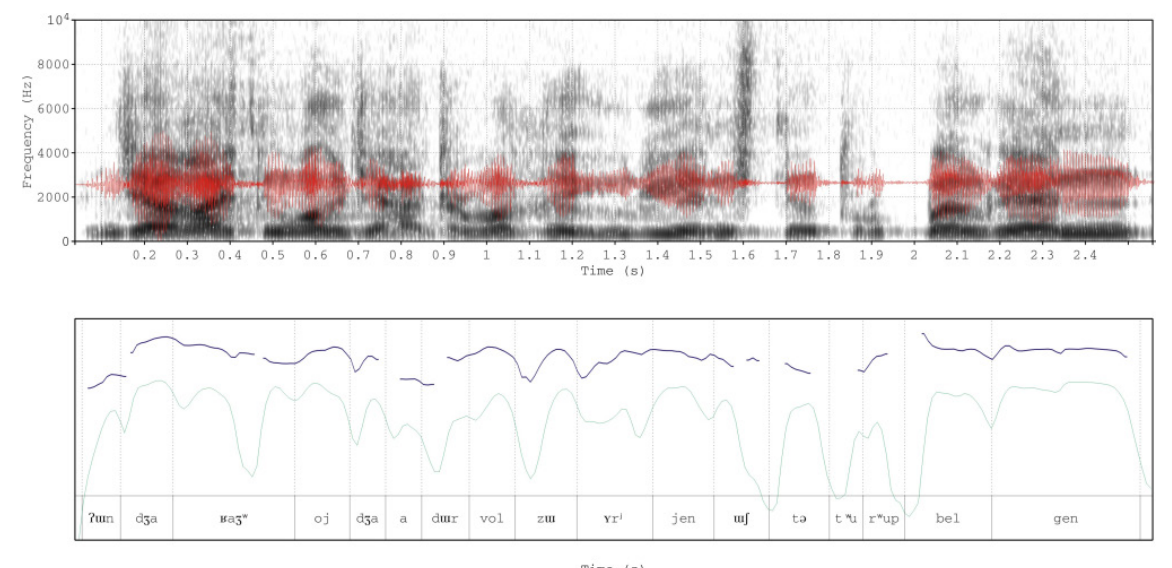

Fig. 7. Intonogram of the Tuvan utterance with the initial metatext marker ynchangash 'therefore'. Рис. 7. Интонограмма тувинской фразы, в начале которой присутствует метатекстовый маркер ынчангаш 'поэтому'.

The adverb ynchangash 'therefore' is used in the final part of the text and is not separated by a pause from the rest of the utterance. Nevertheless, the intonation contour resembles the ones discussed above: F0 movement is rising-falling, with maximum intensity on the second syllable.

(8) Ynchangash eng-ne yrlaar igilder attyng havaanyng kezhinden bolur.

\begin{tabular}{|c|c|c|c|c|}
\hline $\begin{array}{l}\text { ynchangash eng-ne } \\
\text { that is why very-PRTCL } \\
\text { kezh=i=n=den } \\
\text { fell=POSS.3SG=INFIX=ABL }\end{array}$ & $\begin{array}{l}\text { yrla }=\text { ar } \\
\text { sing }=\operatorname{PrP} \\
\text { bol=ur } \\
\text { be }=\operatorname{PrP}\end{array}$ & $\begin{array}{l}\text { igil=der } \\
\text { igil=PL }\end{array}$ & $\begin{array}{l}\text { at=tyng } \\
\text { horse }=\text { GEN }\end{array}$ & $\begin{array}{l}\text { havaa=nyng } \\
\text { forehead=GEN }\end{array}$ \\
\hline
\end{tabular}
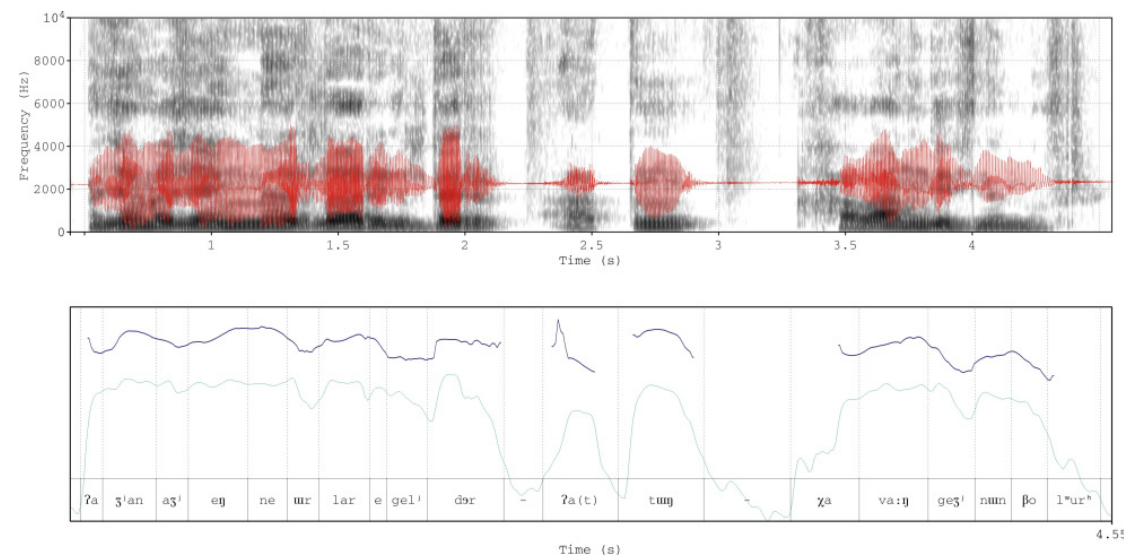

Fig. 8. Intonogram of the Tuvan utterance with the initial metatext marker ynchangash 'therefore'. Рис. 8. Интонограмма тувинского высказывания, в начале которой присутствует метатекстовый маркер ынчангаш 'следовательно, поэтому'.

In the utterance under consideration, ynchangash 'therefore' is characterized by the same rising-falling intonation contour as in the examples above, though the rise is not very sharp. The intensity peak is fixed on the second syllable. There is no pause after the metatext marker.

${ }^{1}$ igil - bowed musical instrument. 
(9) Oon beer Baj-Tajganyng eezi hereezhen kizhi dep chüveni chon ynchaandyr bilip, chugaalazhy bergen yndyg.

$\begin{array}{lllll}\text { oon beer } & \text { Baj-Tajga=nyng } & \text { ee=zi } & \text { hereezhen } & \text { kizhi dep } \\ \text { since that time } & \text { Baj-Tajga=GEN } & \text { host=POSS.3SG } & \text { woman } & \text { person so } \\ \text { chüve=ni } & \text { chon ynchaandyr } & \text { bil=ip } & \text { chugaala=zh=y ber=gen yndyg } \\ \text { thing=ACC } & \text { people thus } & \text { know=CV } & \text { tell=RECIP=CV2 give=PP such }\end{array}$

'Since then, people have learned that the owner of Bai Taiga is a woman.'
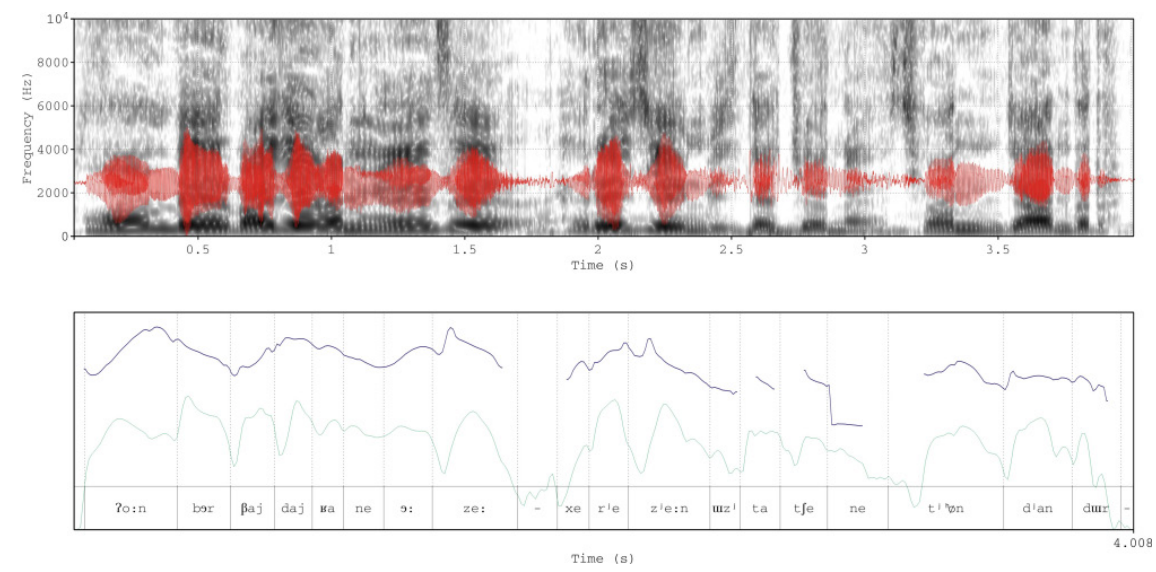

Fig. 9. Intonogram of the Tuvan utterance with the initial metatext marker oon beer 'since that time'. Рис. 9. Интонограмма тувинской фразы, в начале которой присутствует метатекстовый маркер оон бээр 'с тех пор'.

In this example, the sentence starts with the set expression oon beer 'since that time', which is not separated by a pause but has the same tone movement as in previous instances: there is a sharp rise (from 10 st up to $17 \mathrm{st}$ ) on the word oon, which has a long vowel, and thus the whole word is prolonged, followed by a fall (from 17 st to 10 st). Intensity is seen on both constituent words, but its maximum is on beer.

To summarize, the metatext markers considered above can be accompanied both by changes in tone and intensity and by a pause. If they occur at the very beginning or in the middle of the text, they are usually separated from the rest of the utterance by a pause, though they are not detached in the final part of the text. The intonation contour of metatext markers is typically rising-falling. If a metatext marker consists of two words, there may be several peaks of intensity on it.

\section{Tuvan predicative constructions with modal particle -tyr}

The functions similar to those of the established metatext markers are fulfilled by some of the verbal forms.

As in many other Turkic languages, the normal word order in a Tuvan sentence is SOP (subject + object + predicate), with the predicate being rather complicated. The system of Tuvan verb tenses can be found, for example, in (Oorzhak, 2014). L. Shamina has been studying the complex verbal analytic constructions (Shamina, 2005). Of special interest for our work is the article by A. Bayyr-ool (Bayyr-ool, 2013), in which the author considers the occurrence of the special verbform with the modal particle -tyr (with its synharmonic variants -tir, -tur, -tür 'turns out') in the folklore texts. The author suggests that in relation to the folklore texts, the form $=p$-tyr does not have a pronounced meaning of direct evidentiality. The speaker narrates the events known to him/her but not directly observed by himself/herself and without emphasizing the source of the information. In the form $=p$-tyr, mirative semantics, i.e., expression of surprise or admiration both natural and artificial (DeLancy, 2001; Torres, 2011; Rett, Murray, 2013; Kozintseva, 2007; Shamina, 2005; Kaksin, 2013; etc.) is more clearly revealed, while the combination $=p$-tyr evespe conveys the meaning of accentuation with a touch of appeal. The identified meaning of $=p$-tyr and $=p$-tyr evespe and frequency of their use are related to the stylistic properties of the fairytale genre and are dictated by pragmatic goals (Bayyr-ool, 2013: 7). 
In the Tuvan texts under investigation, predicative constructions with the particle -tyr turn out to be frequent. They occur in the complication and ending parts of the texts and often emphasize the connection between the sentence and its previous context, comparable to, for example, ynchangash 'therefore' and ynchap turgash 'thus'. Presented below are several examples of the sentences with the particle -tyr.

Silerning am chylgyngarda Aran-Chula mal bar-dyr. 'In your herd, it turns out, there is a horse Aran-Chula.'

Melegej chylgychylarga sen chylgy kadartyp algan turar-dyr sen. 'It turns out that you entrusted the herd to the stupid herdsmen.'

Konchug-la ekibolgan-dyr, changgys kizhee esh bolur esh-öör chedip kelgen-dir... 'Very well, it turns out, [when] a single person has friends-comrades, it turns out...'

... kadajy amyr-mendi manap olurar boop-tur. '... the wife safe and sound is waiting for [him], it turns out.'

Quite often, the set expression with chüve-dir 'it turns out' is used to express mirativity. In this case, it occurs at the very end of a sentence.

In contrast to the lexical metatext markers, -tyr is not characterized by any intonational prominence, as it is usually situated at the end of an utterance, which is typically pronounced with low intensity and falling tone regardless of the presence of the particle.

(10) Özüp, doruga bergesh, iji hemning ununga iji alyshky chugaalashkan-dyr <...>.

$\begin{array}{llllll}\text { öz=üp } & \text { dorug=a ber=gesh } & \text { iji } & \text { hem=ning } & \text { unun=ga } & \text { iji } \\ \text { grow=CV } & \text { get stronger=CV AUX=CV } & \text { two } & \text { river=GEN } & \text { riverbed=DAT } & \text { two }\end{array}$

alyshky chugaala=sh=kan-dyr

brothers talk=REC=PAST-PRTCL

'[When they] grew up, got stronger, two brothers met on the banks of two rivers, and talked <...>.'
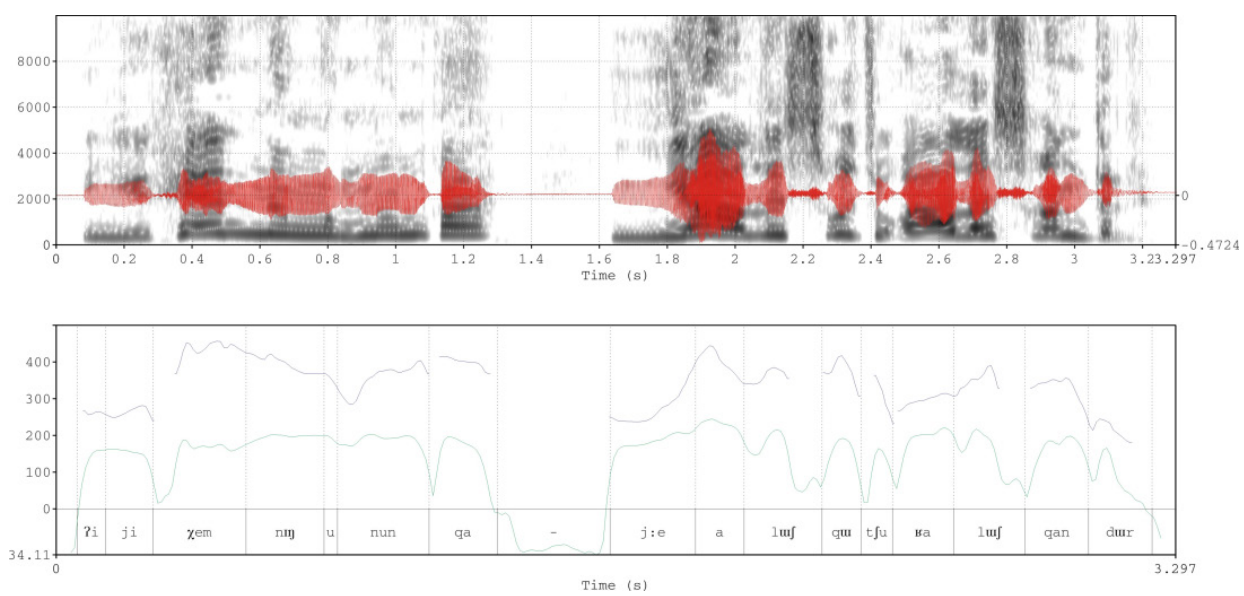

Fig. 10. Intonogram of the Tuvan utterance with the modal particle -tyr 'it turns out'.

Рис. 10. Интонограмма тувинской фразы, в которой присутствует модальная частица -тыр 'оказывается'.

This intonogram shows that the tone and intensity on the modal particle -tyr follow the general line of declination marking the end of the utterance.

\section{Conclusions}

The four Tuvan folklore texts analysed in this paper adhere to the common three-part structure of folklore texts described by V. Propp. As the comparison of the tempo in different parts of the texts has shown, the intonational properties of these parts vary from text to text.

There is a number of set expressions serving as metatext markers uniting the utterances into a coherent text and structuring it to show the sequence of events. The beginning commonly involves the expressions shag shaanda 'once upon a time' or yncharga shaanda 'in old times'. In the complication part, the number of 
set expressions is greater: yncharga 'then', ynchaldyr 'so', ynchap turgash 'thus', oong söölünde 'after that', oon söölzüredir 'afterwards', am 'when', am oon 'then', ol-la 'so', with phrases such as birle kitap'once', birle khün, bir khün 'one day' being not so often utilized. To end the narration, the storytellers usually use oon beer 'since that time' and ynchangash 'therefore'. As our study has shown, these expressions are marked intonationally both by changes in tone and intensity. In addition, a pause can separate the markers if they occur in the very beginning or in the middle of the text, but they are not detached when located in the final part of the text.

As the Tuvan language is regarded as quite complex from the grammatical point of view owing to a complicated predicative system, there are also verbal forms performing functions similar to those of metatext markers. One of the peculiarities of the Tuvan folklore sentences is the use of the special particle -tyr it turns out' to denote mirativity: the speaker might not be a direct observer of the event he or she is telling about, and rather may retell something which is commonly thought to have happened. Contrary to metatext markers, such forms do not appear to be distinguished by means of intonation.

Thus, our data proves that intonation plays an important role in forming the structure of Tuvan folklore texts. This role, however, manifests itself only indirectly, in the way of emphasizing lexical means of marking the progression of the text. The grammatical means are, on the contrary, not accompanied by any specific intonational marking. As these results were obtained on the material of folklore texts and with the specific purpose of describing the usage of intonation on the level of text, they do not characterize the Tuvan intonation system as a whole but rather are meant to be seen as an insight into one of the unique functions that intonation performs. Thus, this investigation can serve as a basis for further comprehensive studies of the Tuvan intonation system, as well as for describing the methods of structuring coherent texts in other Turkic languages.

\section{Acknowledgements}

We would like to thank Dr. A. Bayyr-ool for her precious help in understanding the structure of the Tuvan sentences, for her accurate translation and glossary, and for providing information on Tuvan grammar in general.

\section{REFERENCES}

Alekseev, I. E. (1982) Voprositel'noe predlozhenie v yakutskom yazyke [The interrogative sentence in the Yakut language]. Yakutsk, Kn. izd-vo. 172 p. (In Russ.).

Alekseev, I. E. (1983) Voprositel'noe predlozhenie v yakutskom yazyke (semantiko-intonatsionnoe issledovanie) [The interrogative sentence in the Yakut language: a study ofsemantic and intonation] : Abstract of Diss. ... Candidate of Philology. Alma-Ata. 16 p. (In Russ.).

Alekseev, I. E. (1990) Kommunikativno-intonatsionnaya priroda pobuzhdeniya v yakutskom yazyke [The communicative-intonational nature of motivation in the Yakut language]. In: Tyurkskaya fonetika 90 [Turkic Phonetics-90]: I AllUnion Conference November 26-28, Alma-Ata: abstracts Collection of articles. Editorial board: Abuov G., Bazarbayeva Z., Yunisbekov A., Muratov A., Uvaliev N., Shullenbayeva U. Alma-Ata, Creative production Association “GRIFFIN”. 156 p. P. 9. (In Russ.)

Alekseev, I. E. (1992) Pobuditel'naya fraza v yakutskom yazyke (strukturno-kommunikativnyj aspekt) [The imperative phrase in the Yakut language (structural and communicative aspect)]. Novosibirsk, Nauka. 126 p. (In Russ.)

Alekseev, I. E. (1994) Tipologiya strukturno-kommunikativnykh i intonatsionnykh sistem vyskazyvaniya $v$ yakutskom yazyke [Typology of structural-communicative and intonation systems of utterance in the Yakut language]. Abstract of Diss.... Doctor of Philology. Almaty. 58 p. (In Russ.)

Alekseev, N. A. (1980) Rannie formy religii tyurkoyazychnykh narodov Sibiri [Early forms of religion of the Turkic-speaking peoples of Siberia]. Novosibirsk, Nauka. 318 p. (In Russ.)

Alekseev, N. A. (1992) Traditsionnye religioznye verovaniya tyurkoyazychnykh narodov Sibiri [Traditional religious beliefs of the Turkic-speaking peoples of Siberia]. Novosibirsk, Nauka. 241 p. (In Russ.)

Alieva, N. M. (2007) Eshchyo raz ob intonatsionno-grammaticheskom analize prostykh povestvovatel'nykh predlozhenij v sovremennom anglijskom i azerbajdzhanskom yazykakh. Eksperimental'nye rezul'taty [More on the results of intonation analysis of simple narrative sentences in modern English and Azerbaijani languages: Experimental analysis]. Sovremennye gumanitarnye issledovaniya, no. 3 (16), pp. 126-132. (In Russ.)

Alieva, N. M. (2012) O nekotorykh rezul'tatakh intonatsionnogo analiza prostykh povestvovatel'nykh predlozheniiv sovremennom angliiskom i azerbaidzhanskom yazykakh (Rezul'taty eksperimental'nogo analiza) [On some results 
of intonation analysis of simple narrative sentences in modern English and Azerbaijani languages: Experimental analysis)]. Bulletin KazNU. Filology series, no. 4 (138), pp. 85-88. (In Russ.)

Bavuu-Surun, M. (2010) Tuvinskiy yazyk na sovremennom etape: obrazovatel'nyy aspect [The contemporary Tuvan language : the educational aspect]. New Research of Tuva, no. 3, pp. 57-71. (In Russ.)

Bazarbaeva, Z. M. (2008) Kazakhskaia intonatsia [Kazakh intonation]. Almaty, Dajk-Press. 284 p. (In Russ.)

Baitchura, U. (1959) Kharakter udareniya v misharsko-tatarskom dialekte [The nature of stress in the Mishar-Tatar dialect]. Voprosy yazykoznaniya, no. 2, pp. 113-116. (In Russ.)

Baitchura, U. (1961) Zvukovoj stroj tatarskogo yazyka v svyazi s drugimi tyurkskimi i finno-ugorskimi yazykami [The sound structure of the Tatar language in connection with other Turkic and Finno-Ugric languages]. In 2 parts. Kazan, Kazan University Publ. Part 2. 392 p. (In Russ.)

Baitchura, U. (1970) Instrumental'no-foneticheskie dannye otnositel'no intonatsii i slovesnogo udareniia v tyurkskikh yazykakh [Instrumental and phonetic data on intonation and word stress in the Turkic languages]. Proceedings of the Sixth International Congress of Phonetic Sciences. Prague, Academia Publishing House of the Czechoslovak Academy of Sciences. 1128 p. Pp. 147-167. (In Russ.)

Baitchura, U. (1971) Nekotorye eksperimental'nye dannye o melodike rechi i slovesnom udarenii v uigurskom yazyke [Some experimental data on the melody of speech and word stress in the Uyghur language]. In: Struktura i istoriya tyurkskikh yazykov [Structure and history of the Turkic languages]. Ed. by E. V. Sevortyan. Moscow, Nauka. 306 p. Pp. 42-62. (In Russ.)

Bayyr-ool, A. V. (2013) Semantika form =p-tyr i =p-tyr evespe v fol'klornykh tekstakh tuvinskogo yazyka [Semantics of forms $=p=t y r$ and $=p=t y r$ evespe in Tuvann folklore texts]. Languages and Folklore of Indigenous Peoples of Siberia, no. 2(25), pp. 4-7. (In Russ.)

Bicheldey, K. A. (1989) Glasnye tuvinskogo yazyka $v$ potoke rechi [Vowels of the Tuvan language in the flow of speech]. Kyzyl, s. n. 92 p. (In Russ.)

Bicheldey, K. A. (2001) Faringalizatsiya $v$ tuvinskom yazyke [Pharyngealization in the Tuvan language]. Moscow, RUDN. 289 p. (In Russ.)

Bicheldey, K. N. (2000) Ritmomelodemy prostykh nerasprostranennykh predlozhenii khakasskogo yazyka: Povestvovanie. Vopros. Pobuzhdenie [Rhythmomelodems of simple sentences in the Khakass language: Statement. Question. Imperative]. Moscow, RUDN. 116 p. (In Russ.)

Bicheldey, K. N. (2001) Leksiko-grammaticheskie i ritmomelodicheskie sredstva vyrazheniya voprositel'nosti v khakasskom yazyke [Lexico-grammatical and rhythmomelodic means of expressing interrogativity in the Khakass language]. Moscow, RUDN. 281 p. (In Russ.)

Burnakova, K. N. (1981) Ritmomelodemy khakasskikh prostykh nerasprostranennykh predlozhenii [Rhythmomelodems of Khakass simple nonproliferated sentences]: Diss.... Candidate of Philology. Alma-Ata. 185 p. (In Russ.)

Burnakova, K. N. (1986) Osobennosti i itogi issledovaniia ritmomelodiki khakasskogo iazyka [Features and results of the study of the rhythmomelodics of the Khakass language]. In: Fonetika iazykov Sibiri i sopredel'nykh regionov [Phonetics of the languages of Siberia and adjacent regions] / ed. by V. M. Nadeliaev. Novosibirsk, Nauka. 182 p. Pp. 128-131. (In Russ.)

Burnakova, K. N. (2014) O ritmomelodicheskom issledovanii konstruktsii voprositel'no-pobuditel'nykh predlozhenii (na materiale khakasskogo iazyka) [On the rhythmomelodic study of constructions of interrogative-motivational sentences (based on the material of the Khakass language)]. Rossiiskaia tiurkologiia, no. 1(10), pp. 13-22. (In Russ.)

Wierzbicka, A. (1978) Metatekst v tekste [Metatext in a text]. In: Novoe v zarubezhnoj lingvistike [New in foreign linguistics]. Issue 8. Lingvistika teksta [Text linguistics]. Moscow, Progress. 479 p. Pp. 402-421. (In Russ.)

Veisialli, F. Ya. (2013) Foneticheskii stroi sovremennogo azerbaidzhanskogo iazyka [Phonetic structure of the modern Azerbaijani language]. Baku, Mutardzhim. 144 p. (In Russ.)

Gertsog, O. F. (1986) Ritmomelodika sobstvenno-povestvovatel'nykh predlozhenij telengitskogo dialekta altajskogo yazyka [Rhythmomelodics of declarative sentences in the Telengit dialect of the Altai language]. In: Foneticheskie struktury $v$ sibirskikh yazykakh [Phonetic structures in Siberian languages]. Ed. by E. I. Ubryatova. Novosibirsk, Berdskaya tipographia. 188 p. Pp. 125-143. (In Russ.)

Gertsog, O. F. (1988) Ritmomelodika prostogo predlozheniya telengitskogo dialekta altajskogo yazyka (eksperimental'nofoneticheskoe issledovanie) [Rhythmomelodics of a simple sentence in the Telengit dialect of the Altai language: a study in experimental phonetics]: Abstract of Dis.... Candidate of Philology. Alma-Ata. 19 p. (In Russ.)

Gertsog, O. F. (1989) Ritmomelodika nekotorykh kommunikativnykh vidov voprosov v telengitskom dialekte altaiskogo yazyka [Rhythmomelodics of some communicative types of questions in the Telengit dialect of the Altai language]. In: Zvukovye sistemy sibirskikh yazykov [Sound systems of Siberian languages]. Ed. by E. I. Ubryatova and I. Ya. Selyutina. Novosibirsk, Tipografiia GPNTB SO AN SSSR. 142 p. Pp. 98-108 (In Russ.)

Dambyra, I. D. (2005) Vokalizm kaa-khemskogo govora $v$ sopostavlenii s drugimi govorami i dialektami tuvinskogo yazyka: Monografia [Vocalizm of the Kaa-Khem subdialect in comparison with other subdialects and dialects of the Tuvan language]. Novosibirsk, Sibirskii khronograf. 224 p. (In Russ.) 
Iskhakov, F. G. and Pal'mbakh, A. A. (1961) Grammatika tuvinskogo yazyka. Fonetika i morfologiya [Grammar of the Tuvan language. Phonetics and morphology]. Moscow, Vostochnaia literature. 470 p. (In Russ.)

Kaksin, A. D. (2013) Reprezentatsia evidentsial'nosti i mirativnosti v khakasskom yazyke: sposoby i sredstva [Representing evidentiality and mirativity in the Khakass language: ways and means]. Mir nauki, kul'tury i obrazovaniia, no. 3 (40), pp. 246-249. (In Russ.)

Kechil-ool, S. V. (2006) Tipologicheskaya spetsifika konsonantizma sutkhol'skogo govora $v$ sisteme govorov i dialektov tuvinskogo yazyka: Monografiya [Typological specificity of the consonantism of Syut-Khol subdialect in the system of subdialects and dialects of the Tuvan Language: A monograph]. Novosibirsk, Sova. 362 p. (In Russ.)

Kozintseva, N. A. (2007) Tipologiya kategorii zasvidetel'stvovannosti [The typology of the category of evidentiality]. In: Evidentsial'nost'v yazykakh Evropy i Azii. Sbornik statey pamyati Natalii Andreevny Kozintsevoy [Evidentiality in the languages of Europe and Asia. Collected papers in the memory of N. A. Kozintseva]. Khrakovskiy V. (Ed.). St. Petersburg, Nauka. 634 p. Pp. 13-36. (In Russ.)

Kuzmina, E. N. (2005) Ukazatel' tipicheskikh mest geroicheskogo eposa narodov Sibiri (altaytsev, buryat, tuvintsev, khakasov, shortsev, yakutov): Eksperimental'noye izd. [An index of common places of heroic epic songs of the peoples of Siberia: the Altaians, the Buryats, the Tuvans, the Khakas, the Shors, the Yakuts; An experimental edition]. Novosibirsk, SB RAS Publ. 1383 p. (In Russ.)

Nadelyaev, V. M. (1980) Artikulyatsionnaya klassifikatsiya glasnykh [An articulatory classification of the vowels]. In: Foneticheskie issledovaniya po sibirskim yazykam [Phonetic studies in Siberian languages]. Ed. by V. M. Nadelyaev. Novosibirsk, Tipografiia GPNTB SO AN SSSR. 164 p. Pp. 3-91. (In Russ.)

Nadelyaev, V. M. (1986) K tipologii artikulyatsionno-akusticheskikh baz (AAB) [On the typology of articulatoryacoustic bases (AAB)]. In Foneticheskie struktury $v$ sibirskikh yazykakh [Phonetic structures in the Siberian languages]. Ed. by E. I. Ubryatova. Novosibirsk, Berdskaya tipographia. 188 p. Pp. 3-15. (In Russ.)

Oorzhak, B. Ch. (2014) Vremennaya sistema tuvinskogo yazyka [The system of tenses in the Tuvan language]. Moscow, LRC Publishing House. 184 p. (In Russ.)

Pamiatniki fol'klora narodov Sibiri i Dal'nego Vostoka. Mify, legendy, predaniia tuvintsev [Monuments of folklore of the peoples of Siberia and the Far East. Myths, legends, legends of the Tuvans] (2010) / comp. by A. N. Alekseev et al. Novosibirsk, Nauka. 372 p. (In Russ.)

Propp, V. Ya. (2001) Morfologiya volshebnoy skazki [Morphology of a fairy tale]. Moscow, Labyrint. 192 p. (In Russ.)

Ryzhikova, T., Dobrinina, A., Plotnikov, I., Shestera, E. and Shamrin, A. (2020) Intonatsiya modal'nykh voprositel'nykh vyskazyvaniy v altayskom yazyke (na materiale fol'klora altay-kizhi) [Intonation of modal interrogative utterances in the Altai language; the case ofthe Altai-Kizhi folklore]. Siberian Journal of Philology, no. 2, pp. 149-165. (In Russ.). DOI: https://doi.org/10.17223/18137083/71/13

Salimov, H. H. (1986) Tatarskoe slovesnoe udarenie i kachestvennye izmeneniya glasnykh [Tatar word stress and qualitative changes of vowels]. In : Vopros struktury tatarskogo yazyka [The question of the structure of the Tatar language]. Ed. by M. Z. Zakiev. Kazan, Kazan State Pedagogical Institute. 174 p. Pp. 65-71 (In Russ.)

Salimov, H. H. (1999) Prosodicheskaya sistema tatarskogo yazyka [Prosodic system of the Tatar language]. Diss.... Doctor of Philology. Elabuga, 366 p. (In Russ.)

Sat, Sh. (1983) Amgy tyva literaturlug dyl [Modern Tuvan literary language]. Kyzyl, Tuvan Book Publishing House. 141 p. (In Tuvan).

Sidorova, A. A. (2012) Intonatsionnaia realizatsia obrashchenii v yakutskoi rechi [Intonational implementation of address in the Yakut speech]. Vestnik of NEFU, vol. 9, no. 4, pp. 97-102. (In Russ.)

Turkbenbaev, N. U. (1966) Intonatsia prostykh voprositel'nykh predlozhenii v kazakhskom yazyke [Intonation of simple interrogative sentences in the Kazakh language]: Abstract of Diss. ... Candidate of Philology. Alma-Ata. (In Russ.)

Shamina, L. A. (2005) Sredstva vyrazheniya evidentsial'nosti i mirativnosti v tuvinskom yazyke [Means of expressing evidentiality and mirativity in the Tuvan language]. In: Puti formirovaniya yazykovogo landshafta Sibiri [Ways of formation of the linguistic landscape of Siberia]. Ed. by N. N. Shirobokova. Novosibirsk, Nika. 198 p. Pp. 146-158. (In Russ.)

Shestera, E. A. (2014) Teleutskii yazyk: intonatsiya povestvovatel'nykh i voprositel'nykh vyskazyvanii [Teleut language: intonation of declarative and interrogative utterances]. Voprosy yazykoznaniya , no. 2, pp. 61-76. (In Russ.)

Shestera, E. A. (2018) Teleutskaia, khakasskaia i russkaia intonatsionnye sistemy: sravnitel'no-sopostavitel'nyi analiz [Teleut, Khakas and Russian intonation systems: comparative analysis]. Siberian Philological Journal, no. 2, pp. 251-263. (In Russ.)

Scherbak, A. (1994) Vvedenie $v$ sravnitel'noe izuchenie tyurkskikh yazykov [An introduction into a comparative study of the Turkic languages]. St. Petersburg, Nauka, Sankt-Peterburg. izd. firma. 191 p. (In Russ.)

Yanko, T. E. (1999) O ponyatiyakh kommunikativnoy struktury i kommunikativnoy strategii (na materiale russkogo yazyka) [On the notions of the communicative structure and communicative strategy: the case of Russian language]. Voprosy iazykoznaniia, no. 4, pp. 28-55. (In Russ.) 
DeLancey, S. (2001) The mirativity and evidentiality. Journal of Pragmatics, no. 33 (3), pp. 369-382. DOI: https://doi. org/10.1016/S0378-2166(01)80001-1

Ipek, C. and Jun, S.-A. (2013) Towards a model of intonational phonology of Turkish: Neutral intonation. The Journal of the Acoustical Society of America, no. 133, pp. 3573. DOI: https://doi.org/10.1121/1.4806553

Johanson, L. (1998) The History of Turkic. In: Lars Johanson \& Éva ÁgnesCsató (Eds.). The Turkic Languages. London; New York, Routledge. 474 p. P. 81-125.

Kawaguchi, Y., Yilmaz, S. and Uras, A. (2006) Intonation Patterns of Turkish Interrogatives in Prosody and Syntax. Amsterdam, John Benjamins Publishing Co. P. O. 349 p. DOI: https://doi.org/10.1075/ubli.3.19kaw

Kühn, J. (2016) Functionally-driven language change: Prosodic focus and sentence type marking in German-Turkish bilingual yes/no questions. Thesis ... Doctor of Philosophy. Germany, Univ. of Potsdam. 369 p.

Levi, S. (2002) Intonation in Turkish: the realization of noun compounds and genitive possessive NPs. Ms. University of Washington.

Rett, J. and Murray, S. (2013) A semantic account of mirative evidentials. Semantics and Linguistic Theory, no. 23, pp. 453-472.

Royer, A. J. (2017) Towards a model of Tatar intonational phonology. The Journal of the Acoustical Society of America, no. 142(4), pp. 2519-2519. DOI: https://doi.org/10.1121/1.5014202

Royer, A. and Jun, S.-A. (2018) A Preliminary Model of Tatar Intonational Phonology. In: Proc. 9th International Conference on Speech Prosody. Poznan. 3801 p. Pp. 769-773.

Royer, A. J. and Jun, S. (2019) Prominence marking in Kazan Tatar declaratives. In: Proceedings of the 19th International Congress of Phonetic Sciences, Melbourne, Australia 2019. Ed. by S. Calhoun, P. Escudero, M. Tabain and P. Warren. Australasian Speech Science and Technology Association Inc Melbourne, Canberra, Australia. 12000 p. P. $2995-2599$.

Ryzhikova, T., Dobrinina, A. and Plotnikov, I. (2020) Preliminaries to the Tuvan interrogative intonation. In: Proceedings ExLing 2020: 11th International Conference of Experimental Linguistics, 12-14 October, Athens, Greece. Ed. by A. Botinis. Greece, Athens. 236 p. DOI: https://doi.org/10.36505/ExLing-2020/11

Torres, T. B. (2011) Mirativity as tense/aspect displacement. In: Proceedings of NELS 42. Editors: Stefan Keine \& Shayne Sloggett. Toronto, CreateSpace Independent Publishing Platform. 354 p. Pp. 231-244.

Submission date: 31.08.2021.

\section{СПИСОК ЛИТЕРАТУРЫ}

Алексеев, И. Е. (1982) Вопросительное предложение в якутском языке. Якутск : Книжное издательство. 172 с.

Алексеев, И. Е. (1983) Вопросительное предложение в якутском языке (семантико-интонационное исследование): автореф. дисс. ... канд. филол. н. Алма-Ата. 16 с.

Алексеев, И. Е. (1990) Коммуникативно-интонационная природа побуждения в якутском языке // Тюркская фонетика-90: I Всесоюзная конференция 26-28 ноября г. Алма-Ата: тезисы докладов / редакционная коллегия: Абуов Ж., Базарбаева 3., Джунисбеков А., Муратов А., Увалиев Н., Шуленбаева У. Ленинград : Творческопроизводственное объединение «ГРИФОН». 156 с. С. 9.

Алексеев, И. Е. (1992) Побудительная фраза в якутском языке (структурно-коммуникативный аспект). Новосибирск : Наука. 126 с.

Алексеев, И. Е. (1994) Типология структурно-коммуникативных и интонационных систем высказывания в якутском языке : автореф. дисс.... д. филол. н. Алматы. 58 с.

Алексеев, Н. А. (1980) Ранние формы религии тюркоязычных народов Сибири. Новосибирск : Наука. 318 с.

Алексеев, Н. А. (1992) Традиционные религиозные верования тюркоязычных народов Сибири. Новосибирск : Наука. 241 с.

Алиева, Н. М. (2007) Ещё раз об интонационно-грамматическом анализе простых повествовательных предложений в современном английском и азербайджанском языках. Экспериментальные результаты // Современные гуманитарные исследования. № 3 (16). С. 126-132.

Алиева, Н. М. (2012) О некоторых результатах интонационного анализа простых повествовательных предложений в современном английском и азербайджанском языках (Результаты экспериментального анализа) // Вестник КазНУ. Филология. № 4 (138). С. 85-88.

Бавуу-Сюрюн, М. (2010) Тувинский язык на современном этапе: образовательный аспект // Новые исследования Тувы. № 3. С. 57-71.

Базарбаева, 3. М. (2008) Хакасская интонация. Алматы : Дайк-Пресс. 284 с.

Байчура, У. (1959) Характер ударения в мишарско-татарском диалекте // Вопросы языкознания. № 2. С. $113-116$. 
Байчура, У. (1961) Звуковой строй татарского языка в связи с другими тюркскими и финно-угорскими языками: в 2 ч. Казань: Изд-во Казан. ун-та. Ч. 2. 392 с.

Байчура, У. (1970) Инструментально-фонетические данные относительно интонации и словесного ударения в тюркских языках // Proceedings of the Sixth International Congress of Phonetic Sciences. Prague : Academia Publishing House of the Czechoslovak Academy of Sciences. 1128 c. C. 147-167.

Байчура, У. (1971) Некоторые экспериментальные данные о мелодике речи и словесном ударении в уйгурском языке // Структура и история тюркских языков / отв. ред. Э. В. Севортян. М. : Наука. 306 с. С. $42-62$.

Байыр-оол, А. В. (2013) Семантика формы =п-тыр и =п-тырэвеспе в фольклорных текстах тувинского языка // Языки и фольклор коренных народов Сибири. № 2 (25). С. 4-7.

Бичелдей, К. А. (1989) Гласные тувинского языка в потоке речи. Кызыл : б. и. 92 с.

Бичелдей, К. А. (2001) Фарингализация в тувинском языке. М. : РУДН. 289 с.

Бичелдей, К. Н. (2000) Ритмомелодемы простых нераспространенных предложений хакасского языка: Повествование. Вопрос. Побуждение. М. : РУДН. 116 с.

Бичелдей, К. Н. (2001) Лексико-грамматические и ритмомелодические средства выражения вопросительности в хакасском языке. М. : РУДН. 282 р.

Бурнакова, К. Н. (1981) Ритмомелодемы хакасских простых нераспространённых предложений: дисс. ... кандидата филол. н. Алма-Ата. 185 с.

Бурнакова, К. Н. (1986) Особенности и итоги исследования ритмомелодики хакасского языка // Фонетика языков Сибири и сопредельных регионов / отв. ред. В. М. Наделяев. Новосибирск : Наука. 182 с. С. $128-131$.

Бурнакова, К. Н. (2014) О ритмомелодическом исследовании конструкций вопросительно-побудительных предложений (на материале хакасского языка) // Российская тюркология. № 1(10). С. 13-22.

Вежбицкая, А. (1978) Метатекст в тексте // Новое в зарубежной лингвистике. Вып. 8. Лингвистика текста. М. : Прогресс. 479 с. С. $402-421$.

Вейсялли, Ф. Я. (2013) Фонетический строй современного азербайджанского языка. Баку : Мутарджим. 144 с.

Герцог, О. Ф. (1986) Ритмомелодика собственно-повествовательных предложений теленгитского диалекта алтайского языка // Фонетические структуры в сибирских языках / отв. ред. Е. И. Убрятова. Новосибирск : Бердская типография. 188 с. С. $125-143$.

Герцог, О. Ф. (1988) Ритмомелодика простого предложения теленгитского диалекта алтайского языка (экспериментально-фонетическое исследование): автореф. дисс. ... канд. филол. наук. Алма-Ата. 19 с.

Герцог, О. Ф. (1989) Ритмомелодика некоторых коммуникативных видов вопросов в теленгитском диалекте алтайского языка // Звуковые системы сибирских языков / отв. ред. И. Я. Селютина. Новосибирск : Типография ГПНТБ СО АН СССР. 142 с. С. 98-108.

Дамбыра, И. Д. (2005) Вокализм каа-хемского языка в сопоставлении с другими говорами и диалектами тувинского языка. Новосибирск : Сибирский хронограф. 224 с.

Исхаков, Ф. Г., Пальмбах, А. А. (1961) Грамматика тувинского языка. Фонетика и морфология. М. : Восточная литература. 470 с.

Каксин, А. Д. (2013) Репрезентация эвиденциальности и миративности в хакасском языке: способы и средства // Мир науки, культуры и образования. № 3 (40). С. 246-249.

Кечил-оол, С. В. (2006) Типологическая специфика консонантизма сутхольского языка в системе говоров и диалектов тувинского языка. Новосибирск : Сова. 362 с.

Козинцева, Н. А. (2007) Типология категории доказательности // Эвиденциальность в языках Европы и Азии. Сборник статей памяти НаталииАндреевны Козинцевой / отв. ред. В. Храковский. СПб. : Наука. 634 с. С. $13-36$.

Кузьмина, Е. Н. (2005) Указатель типических мест героического эпоса народов Сибири (алтайцев, бурят, тувинцев, хакасов, шорцев, якутов): Экспериментальное издание. Новосибирск : Изд-во СО РАН. 1383 с.

Наделяев, В. М. (1980) Артикуляционная классификация гласных // Фонетические исследования в сибирских языках / отв. ред. В. М. Наделяев. Новосибирск : Типография ГПНТБ СО АН СССР. 164 с. С. 3-91.

Наделяев, В. М. (1986) К типологии артикуляционно-акустических баз (ААБ) // Фонетические исследования в сибирских языках / отв. ред. Е. И. Убрятова. Новосибирск : Бердская типография. 188 с. С. 3-15.

Ооржак, Б. Ч. (2014) Временная система тувинского языка. М. : Издательство ЦУРА. 184 с.

Памятники фольклора народов Сибири и Дальнего Востока. Мифы, легенды, предания тувинцев (2010) / сост. А. Н. Алексеев и др. Новосибирск : Наука. 372 с.

Пропп, В. Я. (2001) Морфология волшебной сказки. М. : Лабиринт. 192 с.

Рыжикова Т., Добринина А., Плотников И., Шестера Е., Шамрин А. (2020а) Интонация модальных вопросительных высказываний в алтайском языке (на материале фольклора алтай-кижи) // Сибирский филологический журнал. № 2. С. 149-165. DOI: https://doi.org/10.17223/18137083/71/13 
Салимов, Х. Х. (1986) Татарское словесное ударение и качественные изменения гласных // Вопросы структуры татарского языка / отв. ред. М. З. Закиев. Новосибирск : Казанский государственный педагогический институт. 174 с. С. $65-71$.

Салимов, Х. Х. (1999) Просодическая система татарского языка : дисс. ... доктора филол. н. Елабуга. 366 с.

Сат, Ш. (1983) Амгы тыва литературлуг дыл. Синтаксис [Современный тувинский литературный язык. Синтаксис]. Кызыл : ТывНУЧ. 141 с. (На тув. яз.).

Сидорова, А. А. (2012) Интонационная реализация обращений в якутской речи // Вестник Северо-Восточного федерального университета имени М. К. Аммосова. Т. 9. № 4. С. 97-102.

Туркбенбаев, Н. У. (1966) Интонация простых вопросительных предложений в казахском языке : (Эксперим.фонет. исследование) : автореф. дисс.... к. филол. н. Алма-Ата. 21 с.

Шамина, Л. А. (2005). Средства выражения эвиденциальности и миративности в тувинском языке // Пути формирования лингвистического ландшафта Сибири / отв. ред. Н.Н.Широбокова. Новосибирск : Ника. 198 с. С. $146-158$.

Шестера, Е. А. (2014) Телеутский язык: интонация повествовательных и вопросительных высказываний // Вопросы языкознания. № 2. С. 61-76.

Шестера,Е.А. (2018) Телеутская, хакасская и русская интонационные системы: сравнительно-сопоставительный анализ // Сибирский филологический журнал. № 2. С. 251-263.

Щербак, А. (1994) Введение в сравнительное изучение тюркских языков. СПб. : Наука; Санкт-Петербург. изд. фирма. 191 с.

Янко, Т. Е. (1999) О понятиях коммуникативной структуры и коммуникативной стратегии (на материале русского языка) // Вопросы языкознания. № 4. С. 28-55.

DeLancey, S. (2001) The mirativity and evidentiality // Journal of Pragmatics. № 33 (3). P. 369-382. DOI: https://doi. org/10.1016/S0378-2166(01)80001-1

Ipek, C., Jun, S.-A. (2013) Towards a model of intonational phonology of Turkish: Neutral intonation // The Journal of the Acoustical Society of America. № 133. P. 3573. DOI: https://doi.org/10.1121/1.4806553

Johanson, L. (1998). The History of Turkic // Lars Johanson\& Éva ÁgnesCsató (Eds.). The Turkic Languages. London ; New York: Routledge. 474 p. P. 81-125.

Kawaguchi, Y., Yilmaz, S., Uras, A. (2006) Intonation Patterns of Turkish Interrogatives in Prosody and Syntax. Amsterdam : John Benjamins Publishing Co. P.O. 349 p. DOI: https://doi.org/10.1075/ubli.3.19kaw

Kühn, J. (2016) Functionally-driven language change: Prosodic focus and sentence type marking in German-Turkish bilingual yes/no questions. Thesis ... Doctor of Philosophy. Germany: Univ. of Potsdam. 369 p.

Levi, S. (2002) Intonation in Turkish: the realization of noun compounds and genitive possessive NPs. Ms. University of Washington.

Rett, J., Murray, S. (2013) A semantic account of mirative evidentials // Semantics and Linguistic Theory. № 23. P. 453-472.

Royer, A. J. (2017) Towards a model of Tatar intonational phonology // The Journal of the Acoustical Society of America. № 142(4). P. 2519-2519. DOI: https://doi.org/10.1121/1.5014202

Royer, A. J. (2017) Towards a model of Tatar intonational phonology // The Journal of the Acoustical Society of America. № 142(4). P. 2519-2519. DOI: https://doi.org/10.1121/1.5014202

Royer, A. J., Jun, S. (2019) Prominence marking in Kazan Tatar declaratives // Proceedings of the 19th International Congress of Phonetic Sciences, Melbourne, Australia 2019. Ed. by S. Calhoun, P. Escudero, M. Tabain and P. Warren. Australasian Speech Science and Technology Association Inc Melbourne, Canberra, Australia. 12000 p. P. $2995-2599$.

Royer, A. J., Jun, S.-A. (2018) A Preliminary Model of Tatar Intonational Phonology // Proc. 9th International Conference on Speech Prosody. Poznan. 3801 p. P. 769-773.

Ryzhikova, T., Dobrinina, A., Plotnikov, I. (2020) Preliminaries to the Tuvan interrogative intonation // Proceedings ExLing 2020: 11th International Conference of Experimental Linguistics, 12-14 October, Athens, Greece. Ed. by A. Botinis. Greece : Athens. 236 p. DOI: https://doi.org/10.36505/ExLing-2020/11

Torres, T. B. (2011) Mirativity as tense/aspect displacement // Proceedings of NELS 42. Editors: Stefan Keine \& Shayne Sloggett. Toronto : CreateSpace Independent Publishing Platform. 354 p. P. 231-244.

Дата поступления: 31.08.2021 2. 